Article

\title{
Apoptosis, Induced by Human $\alpha$-Synuclein in Yeast, Can Occur Independent of Functional Mitochondria
}

\author{
Damilare D. Akintade ${ }^{1,2, *(1)}$ and Bhabatosh Chaudhuri ${ }^{2}$ \\ 1 School of Life Sciences, Medical School, University of Nottingham, Nottingham NG7 2UH, UK \\ 2 Leicester School of Pharmacy, De Montfort University, Leicester LE1 9BH, UK; BChaudhuri@dmu.ac.uk \\ * Correspondence: Damilare.Akintade@nottingham.ac.uk; Tel.: +44-07712452922
}

Received: 22 August 2020; Accepted: 24 September 2020; Published: 29 September 2020

\begin{abstract}
Human $\alpha$-synuclein expression in baker's yeast reportedly induces mitochondria-dependent apoptosis. Surprisingly, we find that, under de-repressing conditions of the inducible MET25/GAL1 promoters, yeast cells expressing chromosomally-integrated copies of the human $\alpha$-synuclein gene are not killed, but spontaneously form respiration-deficient rho-minus $\left(\rho^{-}\right)$petites. Although yeast cells can undergo cell death (apoptosis) from loss of mitochondrial function, they can also survive without functional mitochondria. Such cells are referred to as $\rho^{0}$ or $\rho^{-}$petites. This study reports that minimal expression of human $\alpha$-synuclein in yeast, from MET25/GAL1 promoter, gives rise to $\rho^{-}$petites. Interestingly, the full expression of $\alpha$-synuclein, from the same promoters, in $\alpha$-synuclein-triggered $\rho^{-}$petites and also in $\rho^{0}$ petites (produced by treating $\rho^{+}$cells with the mutagen ethidium bromide) initiates apoptosis. The percentages of petites increase with increasing $\alpha$-synuclein gene copy-number. $\rho^{-}$petites expressing $\alpha$-synuclein from fully-induced MET25/GAL1 promoters exhibit increased ROS levels, loss of mitochondrial membrane potential, and nuclear DNA fragmentation, with increasing copies of $\alpha$-synuclein. Our results indicate that, for the first time in yeast, $\alpha$-synuclein-triggered apoptosis can occur independently of functional mitochondria. The observation that $\alpha$-synuclein naturally forms petites and that they can undergo apoptosis may have important implications in understanding the pathogenesis of Parkinson's disease.
\end{abstract}

Keywords: human $\alpha$-synuclein; mitochondria-dependent; mitochondria-independent; yeast petites; yeast apoptosis

\section{Introduction}

The yeast Saccharomyces cerevisiae is an attractive tool for the elucidation of human cells' diverse biochemical pathways, which includes mitochondria-dependent apoptosis, a form of programmed cell death [1-3]. It has been reported that apoptosis was induced in aged yeast cells by human $\alpha$-synuclein ( $\alpha$-syn) overproduction; meanwhile, it was thought to cause Parkinson's disease (PD) in human neuronal cells (PD) [4], occurs in the presence of functional mitochondria [5]. Moreover, in both yeast and human neurons, $\alpha$-syn's toxicity seems to be dependent on mitochondrial outer membrane regulator (VDAC) that controls the influx and efflux of metabolites in and out of the mitochondria [6].

Mitochondria, in $\rho^{+}$grande (i.e., normal) cells, are involved in respiration through oxidative phosphorylation. Ineffective mitochondrial oxidative phosphorylation can cause cellular stress in $\rho^{+}$cells leading to overproduction of ROS $[7,8]$, which, in turn, can result in mitochondrial dysfunction [8]. Thus, rho-zero $\left(\rho^{0}\right)$ and rho-minus $\left(\rho^{-}\right)$petites, cells that have lost their respiratory capacity, are formed. The $\rho^{0}$ petites lack mitochondrial DNA (mtDNA), and therefore, have no mitochondrial function [9]. Although $\rho^{-}$petites contain mtDNA, deletions/mutations in their mtDNA cause mitochondrial dysfunction; also, mutations in nuclear genes, that affect mitochondrial function, are involved in the formation of $\rho^{-}$petites. Since Glycerol only allows respiratory growth, both $\rho^{0}$ and 
$\rho^{-}$yeast petites cannot grow in cell culture medium containing Glycerol as the sole carbon source [10]. However, $\rho^{-}$yeast cells can be distinguished from $\rho^{0}$ petites by the green-fluorescent dye SYTO18, which selectively stains yeast mtDNA [11].

Partial mitochondrial dysfunction, as seen in $\rho^{-}$yeast petites, is linked to the symptoms of Parkinson's disease (PD) $[12,13]$. $\mathrm{P}^{-}$yeast cells also share greatly diminished activity of the mitochondrial electron transport chain with dopaminergic neurons of patients who have Parkinson's disease (PD). Neuronal cell death in PD, as in $\alpha$-syn-induced yeast apoptosis, occurs from complete loss of mitochondrial function $[14,15]$.

A-syn, a presynaptic neuronal protein linked genetically and neuropathologically to PD [16], exists in a soluble monomeric form that is in equilibrium with its soluble oligomeric form, an insoluble fibrillar $\alpha$-syn aggregate [17]. Although the exact physiological function of $\alpha$-syn is not clear [18], $\alpha$-syn aggregation constitute a significant factor in PD pathogenesis [19]. Through its mitochondria-targeting amino terminus that interacts with mitochondrial complex I function [18], wild-type and mutant $\alpha$-syn overexpression can cause mitochondrial damage in neurons through the formation of intra-cytoplasmic fibrillar aggregates, known as Lewy bodies [20]. The $\alpha$-syn A53T mutant protein, which is linked to early-onset $\mathrm{PD}$, is much more prone to aggregation than the wild-type protein [21].

Growth of yeast cells in a medium that contains an mtDNA replication inhibitor and/or inhibitor of mitochondrial protein synthesis can result in partial or complete loss of mtDNA, giving rise to respiratory-deficient $\rho^{-}$and $\rho^{0}$ petite yeast cells, respectively [22]. However, in human cells, the petite formation can occur spontaneously when mitochondrial function is partially disturbed by mtDNA mutations. This is the basis of most human neurological disorders [23]. Remarkably, artificially-created mtDNA-lacking human $\rho^{0}$ cells [24], although more resistant to apoptosis than $\rho^{+}$cells, can still undergo cell death [25]. This is in contrast to the observation that cells with a deficiency in their respiratory chain may have increased apoptosis in vivo [26]. Interestingly, human $\rho^{-}$cells, partially depleted of mtDNA, preserve major apoptotic features, such as loss of mitochondrial membrane potential (MMP) and release of mitochondrial proteins [27]. Hence, it can be inferred that the execution of apoptosis can occur in human cells that have lost mtDNA partially or entirely.

In theory, yeast petites can be used to find out if, like human cells, they also can undergo apoptosis. There is a report indicating that $\rho^{+}$grande yeast cells treated with high concentrations of bleomycin do undergo mitochondria-independent apoptosis [28]. However, it seems that, in general, the presence of functional mitochondria is essential for yeast apoptosis induced by a variety of factors. These include heterologous expression of human proteins $\alpha$-syn [29], and proapoptotic Bax of the Bcl-2-family [30], the process of cellular ageing [31], defects in actin function [32], acetic acid treatment of cells [33], and prolonged cell exposure to mating factors [34], plant toxins [35], osmotic stress [36], high pH environment [37], and lipid peroxidation [38]. Yeast cells facing stress from any of these factors, including that of $\alpha$-syn expression, a prompt rise of intracellular ROS levels that lead to dysfunctional mitochondria, measured by a decrease in MMP, and ultimately to apoptosis [39-41]. In neuronal cells too, expression of $\alpha$-syn causes an increase in ROS production, the opening of mitochondrial permeability transition pore, decrease in MMP, and eventual cell death [42].

This study describes the unexpected findings that very low levels of wild-type human $\alpha$-syn expression in yeast, obtained through de-repression of the inducible MET25 or GAL1 promoter, spontaneously cause the formation of $\rho^{-}$petites, which undergo apoptosis when the promoters are fully induced (i.e., when higher levels of $\alpha$-syn are produced). Even in the absence of mtDNA, $\alpha$-syn-expressing $\rho^{0}$ cells, generated by treating with the chemical mutagen ethidium bromide, undergo nuclear DNA fragmentation (a hallmark of apoptosis). This is the first time that it is being described that, in the absence of functional mitochondria, $\alpha$-syn can trigger apoptosis in yeast cells. It should be noted that $\rho^{-}$petites are not formed in yeast cells minimally expressing the A53T mutant $\alpha$-syn [21], but instead, cells directly undergo apoptosis (data not shown). The results presented here could have broader implications in understanding the pathogenesis and pathophysiology of Parkinson's disease. 


\section{Materials and Methods}

\subsection{Yeast Strains}

The yeast strain W303-1A Mata (ATCC \#208352), referred to in this study as BC300 and is auxotrophic for the genes ADE2, HIS3, LEU2, TRP1 and URA3. New yeast strains were derived from BC300 by transforming integrative plasmids (Supplementary Materials, Parts 1 and 2), which would express $\alpha$-syn from the MET25 or GAL1 promoter. The $\rho^{0}$ petites were obtained from the $\rho^{+}$(grande) BC300 strain through ethidium bromide mediated loss of mtDNA, using a published protocol [43]. In brief, BC300 was grown in full YPD liquid medium containing 4\% glucose and ethidium bromide $(20 \mu \mathrm{g} / \mathrm{mL})$ overnight. The harvested cells were mostly $\rho^{0}$; they grew on YPD, but not on YP-glycerol plates, and did not contain mtDNA.

\subsection{Yeast Transformation}

Plasmids bearing $\alpha$-syn gene expression cassettes under the control of either the methionine-repressible MET25 or galactose-inducible GAL1 promoter (MET25p/GAL1p; see Supplementary Materials, Parts 1 and 2) were used for genomic integration at the TRP1, HIS3, and URA3 chromosomal loci of the $\rho^{+}$BC300 strain to yield strains that contain 1-3 copies of $\alpha$-syn. The integrative transformation was carried out using a published protocol [44]. Similarly, a $\rho^{0}$ BC300 strain was sequentially transformed with integrative plasmids bearing only the MET25p- $\alpha$-syn expression cassettes to obtain $\rho^{0}$ strains that contain 1-3 copies of $\alpha$-syn. The table is shown in Part 6 (Supplementary Materials).

\subsection{SYTO18 Staining of $m t D N A$}

SYTO18 (Molecular Probes; \#Y7530) is a green fluorescent dye that selectively stains yeast mtDNA $[45,46]$. After the expression of $\alpha$-syn in yeast, $\sim 1 \times 10^{6}$ cells were suspended in $1 \mathrm{~mL}$ of $10 \mathrm{mM}$ HEPES buffer ( $\mathrm{pH} 7.4$; containing 5\% glucose). A $10 \mu \mathrm{M}$ final concentration of SYTO18 was added to cells, which were then incubated at room temperature for $5 \mathrm{~min}$. Cells were pelleted and re-suspended in fresh $10 \mathrm{mM}$ HEPES buffer ( $\mathrm{pH} 7.4$; containing 5\% glucose). Fluorescent cells were visualized using a fluorescence microscope.

\subsection{Detection of Dead Cells with Phloxine B Dye}

Cell death was assessed by staining cells with the red dye Phloxine B (Sigma, Dorset, UK. P-4030-25G) [47]. Live cells expel the dye, whereas it is accumulated in dead cells. This can be observed by fluorescence microscopy. Staining experiments were performed exactly as published earlier [48].

\subsection{Detection of ROS}

AAT Bioquest (Sunnyvale, CA, USA) Fluorimetric Intracellular Total ROS Activity Assay Kit (\#22901) was used for measuring ROS. Experiments were performed as published earlier [48].

2.6. Assessing the Presence/Absence of Mitochondrial Membrane Potential (MMP) by Staining Live Cells with the Dye DiOC6(3)

The DiR dye (AAT Bioquest; Sunnyvale, CA, USA \#22046), belonging to the $\mathrm{DiOC}_{6}(3)$ (3,3'-dihexyloxacarbocyanine iodide) family of fluorescent stains, is a deep red lipophilic agent that accumulates in mitochondria of live cells when used at low concentrations. It is used to monitor mitochondrial membrane potential (MMP). The DiR/DiOC 6 (3) dye was used to confirm the presence or absence of MMP in (visually ${ }^{-}$and $\rho^{0}$ yeast petites. After cells were grown for expression of $\alpha$-syn, OD600 was measured, and cells were counted. $1 \times 10^{6}$ cells were suspended in $1 \mathrm{~mL}$ of $10 \mathrm{mM}$ HEPES buffer, containing $5 \%$ glucose, at $\mathrm{pH} 7.4$. A final concentration of $175 \mathrm{nM}$ of $\mathrm{DiOC}_{6}(3)$ was added to 
cells and incubated at room temperature for $13 \mathrm{~min}$. Imaging was done with an Olympus fluorescence microscope (Essex, UK) (at excitation/emission 484/501 nm) with a Leica digital imaging camera.

\subsection{Quantifying Mitochondrial Membrane Potential (MMP) with the JC-10 Dye}

AAT Bioquest (Sunnyvale, CA, USA) JC-10 Mitochondrial Membrane Potential Assay kit (\#22800) uses water-soluble JC-10 to determine MMP quantitively. Experiments were conducted as per the published protocol [48].

\subsection{Staining with Hoechst Dye for Monitoring Live Cells}

Hoechst 33,258 (Thermo Fisher Scientific, Loughborough, UK; \#H21491) is a nucleic acid stain widely used to detect live cells. When bound to double-stranded DNA, the dye emits blue fluorescence. Staining with the dye was performed as described earlier [48].

\subsection{Assessing Nuclear DNA Fragmentation via the TUNEL Assay. AA}

AAT Bioquest (Sunnyvale, CA, USA) TUNEL Apoptosis Assay kit (\#22844) was used for the detection of nuclear DNA fragmentation (NDF). The assays were performed as described earlier [48].

\subsection{Western Blotting}

Western blotting was carried out using standard protocols [49], using primary antibodies specific to $\alpha$-syn (Proteintech; Manchester, UK \#10842-1-AP) or $\beta$-actin (Proteintech; Manchester, UK \#60008-1-Ig).

\subsection{Quantification of Petite formation}

After transformation, colonies of transformants were screen on YP-Gly (with Glycerol as the carbon source). Moreover, after the growth of yeast cell under de-repressing condition, 200 cells were spread on a YPD plate, colonies were then screened on the YPGly agar plate. In both cases, cells that grew (Grande cells) on YPGly were counted, and cells that did not grow (Petite) on YPGly were also counted.

\section{Results and Discussion}

3.1. Minimal Expression of Human $\alpha$-Syn in Yeast from the MET25 or GAL1 Promoters (MET25p or GAL1p), under De-Repressing Conditions, Produces Petites

During the process of sequential chromosomal integration of MET25p or GAL1p-driven human $\alpha$-syn gene-expression cassette-bearing plasmids (Supplementary Materials, Parts 1 and 2) to obtain yeast strains containing 1, 2, and 3 copies of the $\alpha$-syn gene, it was found, after $72 \mathrm{~h}$ incubation at $30{ }^{\circ} \mathrm{C}$, that a percentage of transformants did not grow on solid-agar complete YP medium plates that contained Glycerol as the sole carbon source (Figure 1C,D; non-shaded bars; the only exception, where all transformants grew on Glycerol, were cells containing 1-copy MET25p- $\alpha$-syn). This suggested that transformants that did not grow on Glycerol could not respire aerobically (i.e., were respiration-deficient), as Glycerol is strictly a respiratory carbon source. When MET25p or GAL1p is de-repressed, $\alpha$-syn protein is minimally expressed. Figure 1A,B show levels of $\alpha$-syn protein present in $100 \mu \mathrm{g}$ of cell lysate. 
(A) MET25 p-a-syn

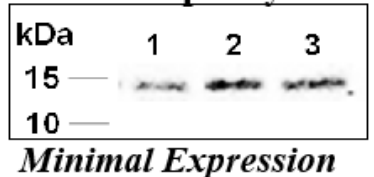

(B)

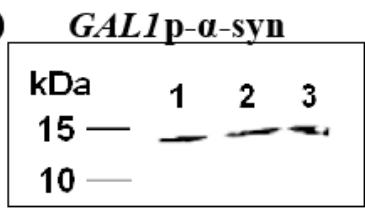

Minimal Expression
(C) Percentage of yeast petites formed, after $72 \mathrm{~h}$,

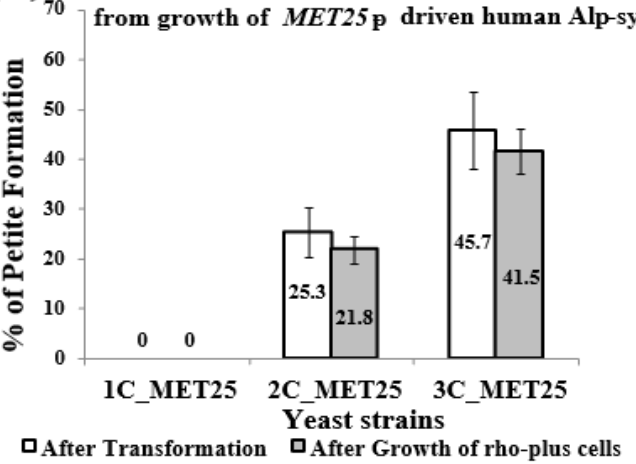

(D) Percentage of yeast petites formed, after $72 \mathrm{~h}$, from growth of GAL1p driven human Alp syn

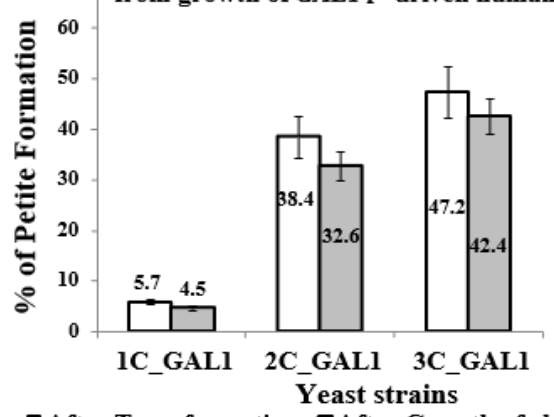

$\square$ After Transformation $\square$ After Growth of rho-plus cells

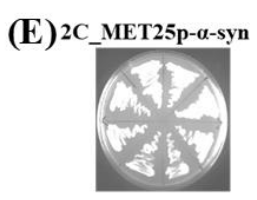

YPD

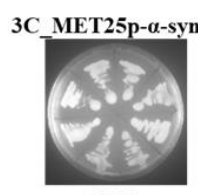

YPD

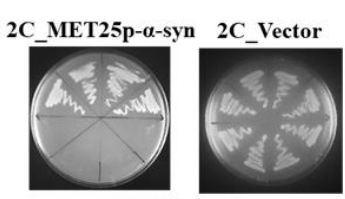

YP-Glycerol

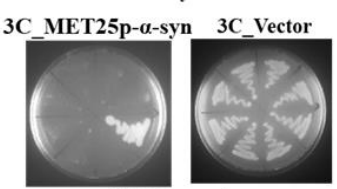

YP-Glycerol

(F)

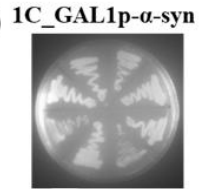

YPD 2C_GAL1p- $\alpha-$ sy

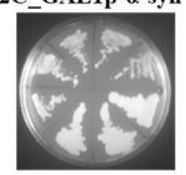

YPD

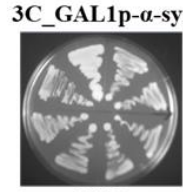

YPD

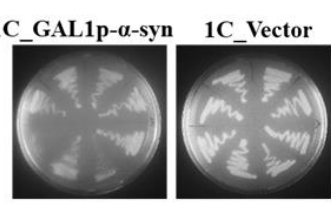

YP-Glycerol

2C_GAL1p- $\alpha$-syn 2C_Vector

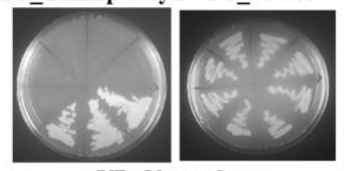

YP-Glycerol

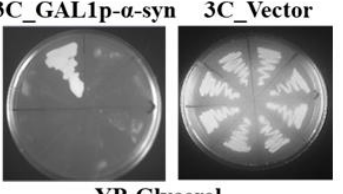

Figure 1. Petites obtained after minimal expression of $\alpha$-syn from the MET25 or GAL1 promoter. $(\mathbf{A}, \mathbf{B})$ Western blot analyses of cells expressing 1 to 3 copies of $\alpha$-syn protein from either MET25p (A) or GAL1p (B) The blots were probed with an antibody that recognizes $\alpha$-syn protein (Proteintech, 10842-1-AP); (C,D) The percentage of petites formed (in cells containing 1-3 copies of $\alpha$-syn under the control of MET25p/GAL1p) from a total of 50 transformants (non-shaded bars) or in 200 cells obtained. The data represent the mean \pm S.D. of three independent experiments. Post Hoc Newman-Keuls test was carried out after a significant ANOVA test, indicating a significant difference $p<0.01$ in petites formed between cells expressing 1opy and 2 or 3-copies of $\alpha$-syn. (E,F) Representative pictures of growth of yeast cells harboring 1-copy (1C), 2-copies (2C), and 3-copies (3C) of the human $\alpha$-syn gene, under the control of MET25p (E) and GAL1p (F), on complete medium solid agar plates that contained either glucose (YPD; plates 1) or Glycerol (YP-glycerol; plates 2). 'Vector' represents cells that contain empty plasmid(s), with no $\alpha$-syn gene, grown on YP-glycerol (plates 3 ). 
Hence, it was inferred that they were petites. It was, therefore, decided to grow normal, non-petite, $\rho^{+}$transformants under conditions that allow de-repression of the promoters to see if $\alpha$-syn-bearing petites were formed spontaneously.

For strains containing 1-3 copies of the $\alpha$-syn gene under the control of the MET25p, cells were grown for $72 \mathrm{~h}$ in glucose-containing SD minimal medium that contained $675 \mu \mathrm{M}$ methionine for repression of MET25p; over a 72-h growth period, in the presence of methionine, there may be mild de-repression of the MET25p because the methionine concentration used to repress the promoter may not entirely block transcription of the downstream $\alpha$-syn gene [50]. For strains containing 1-3 copies of the $\alpha$-syn gene under the control of the GAL1p, cells were grown for $72 \mathrm{~h}$ in SD medium; under these conditions, in the presence of ethanol, which is produced upon complete conversion of glucose to ethanol after 12-13 $\mathrm{h}$ of cell growth, GAL1p is de-repressed [51].

This is in contrast to the much higher levels of $\alpha$-syn protein obtained from fully induced MET25p/GAL1p where only 7.5 ug of cell lysates were used for Western blots (Figure 2G,H).

The percentages of petites formed in liquid culture, under de-repressing conditions of growth of cells containing human $\alpha$-syn gene downstream of the MET25/GAL1 promoters (Figure 1C,D; shaded bars), were confirmed by replica-plating cells from complete YPD-agar plates (that contained glucose; plates 1 in Figure 1E,F) on to YP-glycerol agar plates (that contained Glycerol; plates 2 in Figure 1E,F). Cells that do not grow in Glycerol are the petites, and the ones that do grow in Glycerol are $\rho^{+}$ grande cells. Plates 3 (in Figure 1E,F) display cells containing empty plasmids (i.e., that bear no $\alpha$-syn gene), which show that petites are not formed in the absence of $\alpha$-syn. Moreover, as observed during transformation, petites are not formed in cells expressing 1-copy MET25p- $\alpha$-syn (results not shown). The petite percentages formed in liquid minimal medium culture are similar to the percentages of transformant colonies that were identified as petites after integrative transformation of the basic $\rho^{+}$ yeast strain BC300 (i.e., W303-1A) with the $\alpha$-syn-bearing plasmids (compare shaded and non-shaded bars in Figure 1C,D).

\subsection{Expression, in $\rho^{-}$Yeast Petites, of Human $\alpha$-Syn Gene from Fully-Induced MET25p/GAL1p Retards Cell Growth and Causes Cell Death}

The promoters MET25p and GAL1p were then induced so that $\alpha$-syn could be fully expressed in the petites that had been formed by minimal expression of $\alpha$-syn. The full expression of $\alpha$-syn from the MET25p occurs in glucose-containing complete YPD medium without the addition of methionine. In contrast, galactose-containing complete YP-galactose medium fully induces $\alpha$-syn expression from the GAL1p. Growth of petite cells (which did not grow in YP-glycerol medium; Figure 1E,F) fully expressing $\alpha$-syn in liquid YPD or YP-galactose medium were monitored over $50 \mathrm{~h}$ at $30{ }^{\circ} \mathrm{C}$, $180 \mathrm{rpm}$. There was no growth in petites expressing $\alpha$-syn from the GAL1p (Figure 2B), whereas for petites expressing $\alpha$-syn from the MET25p, there was initial growth which plateaued off after $24 \mathrm{~h}$ (Figure 2A). It was confirmed that petite cells, grown in an appropriate expression medium for $50 \mathrm{~h}$, contained mtDNA by staining with SYTO18, a green fluorescent dye that selectively stains yeast mtDNA (Figure 2C,D) [45], indicating that the petites were $\rho^{-}$. Staining with Phloxine B, which stains only dead cells red [47], showed that $\alpha$-syn-expressing $\rho^{-}$cells underwent cell death (Figure 2E,F). It was observed that cell death gradually increases with increasing $\alpha$-syn copy-number. This mirrored increasing levels of the $\alpha$-syn protein produced in cells expressing 1-3 copies of $\alpha$-syn, from the MET25 or GAL1 promoter (Figure 2G,H; also see densitometric quantification of $\alpha$-syn bands in Supplementary Materials, Parts 3 and 4). 


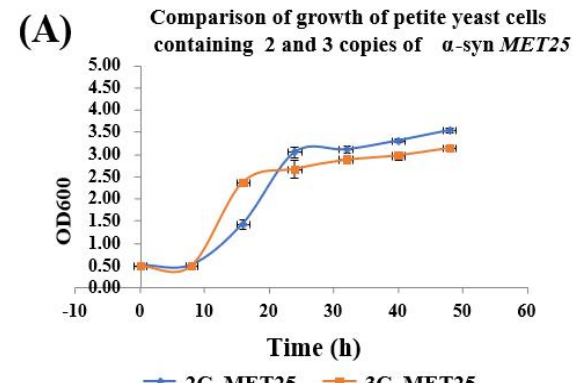

$\rightarrow$ 2C_MET25 $\rightarrow$ 3C_MET25

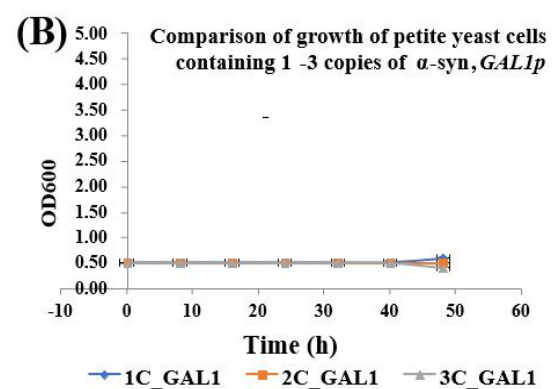

(E)

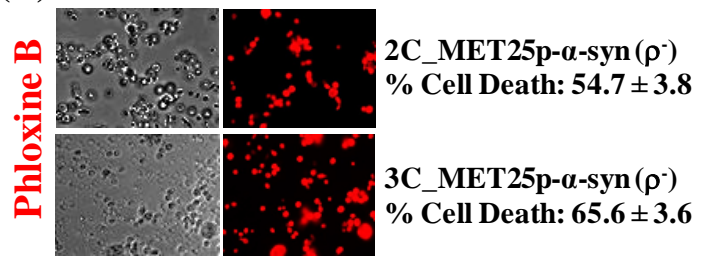

(G)

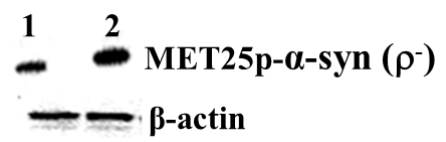

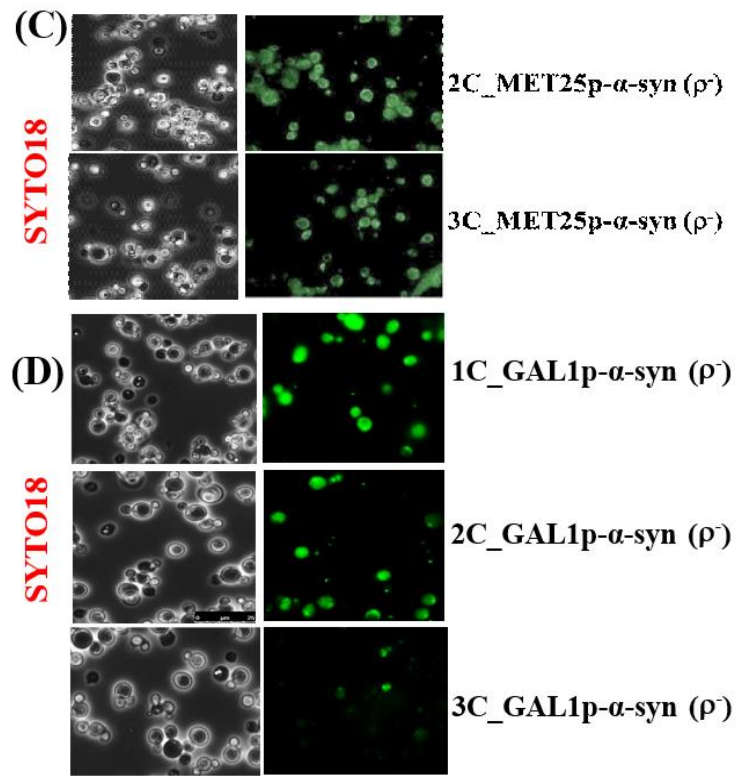

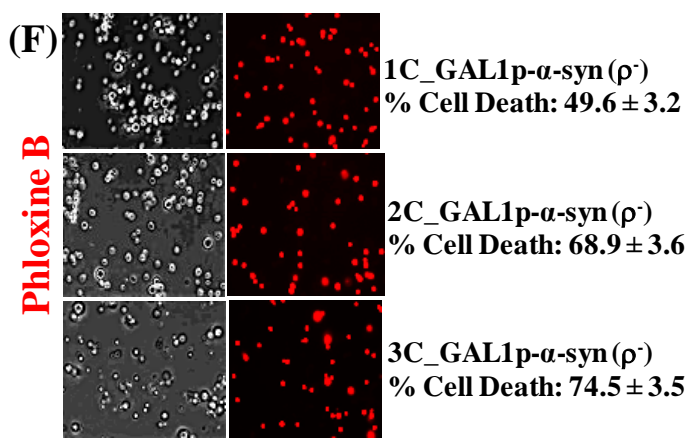

(H)

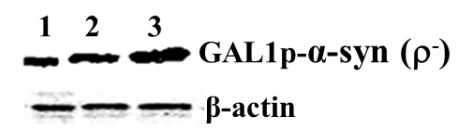

Figure 2. (A,B) Comparison of the growth curves of $\rho^{-}$cells expressing $2-3$ copies of $\alpha$-syn from MET25p (A) and 1-3 copies of $\alpha$-syn from GAL1p (B); cells were grown in YPD (A) and YP-galactose (B). Bonferroni post hoc test after a significant two-way ANOVA indicates no significant difference in growth between yeast petites that contain different copies of the $\alpha$-syn gene. (C,D) Microscopic images $(\times 400)$ of petite cells, where expression of $2-3$ copies (MET25p) or 1-3 copies (GAL1p) of $\alpha$-syn gene was induced, stained with the dye SYTO18. (E,F) Microscopic images $(\times 400)$ of petite cells expressing 2-3 copies of $\alpha$-syn from the MET25p (E) and 1-3 copies of $\alpha$-syn from the GAL1p, staining with Phloxine B. $(\mathbf{G}, \mathbf{H})$ Western blot analyses of cells expressing 1 to 3 -copies of $\alpha$-syn protein after full induction of the MET25p (G) or GAL1p (H). On lanes, 1, $2(\mathbf{G})$ and 1, 2 and $3(\mathbf{H})$ were loaded $7.5 \mu \mathrm{g}$ of total protein obtained after lysis of cells that express 2-copies or 1-copy (lanes $1 ; \mathbf{G}, \mathbf{H})$, 3-copies or 2-copies (lanes 2; G,H) and 3-copies (lane 3; H) of $\alpha$-syn, after the growth of cells under conditions that fully induce the MET25 or GAL1 promoter. The upper panel was probed with an antibody that recognizes human $\alpha$-syn (Proteintech, \#10842-1-AP) and the lower panel with a $\beta$-actin antibody (Proteintech, 60008-1-Ig); Densitometric quantification of the $\alpha$-syn bands in $(\mathbf{G}, \mathbf{H})$ is shown in Supplementary Materials, Parts 3 and 4. Post Hoc Newman-Keuls test, after a significant one-way ANOVA test, indicated a significant difference in cell death, $p<0.01$, between petites expressing $\alpha$-syn with different copy numbers. 
3.3. After Full Induction of MET25/GAL1 Promoter, Human $\alpha$-Syn Expressing $\rho^{-}$Yeast Petites Undergo Loss of MMP and Increase in Nuclear DNA Fragmentation upon Gradual Increase of $\alpha$-Syn Copy Number from 2-3 or 1-3 Copies

The integrity of mitochondrial membranes, within $\alpha$-syn expressing $\rho^{-}$yeast petites, were then monitored using the red fluorescent DiR dye, a variant of the dye 3,3'-dihexyloxacarbocyanine iodide, DiOC6(3), which stains functional mitochondrial membranes [5]; see Figure 3A,B.
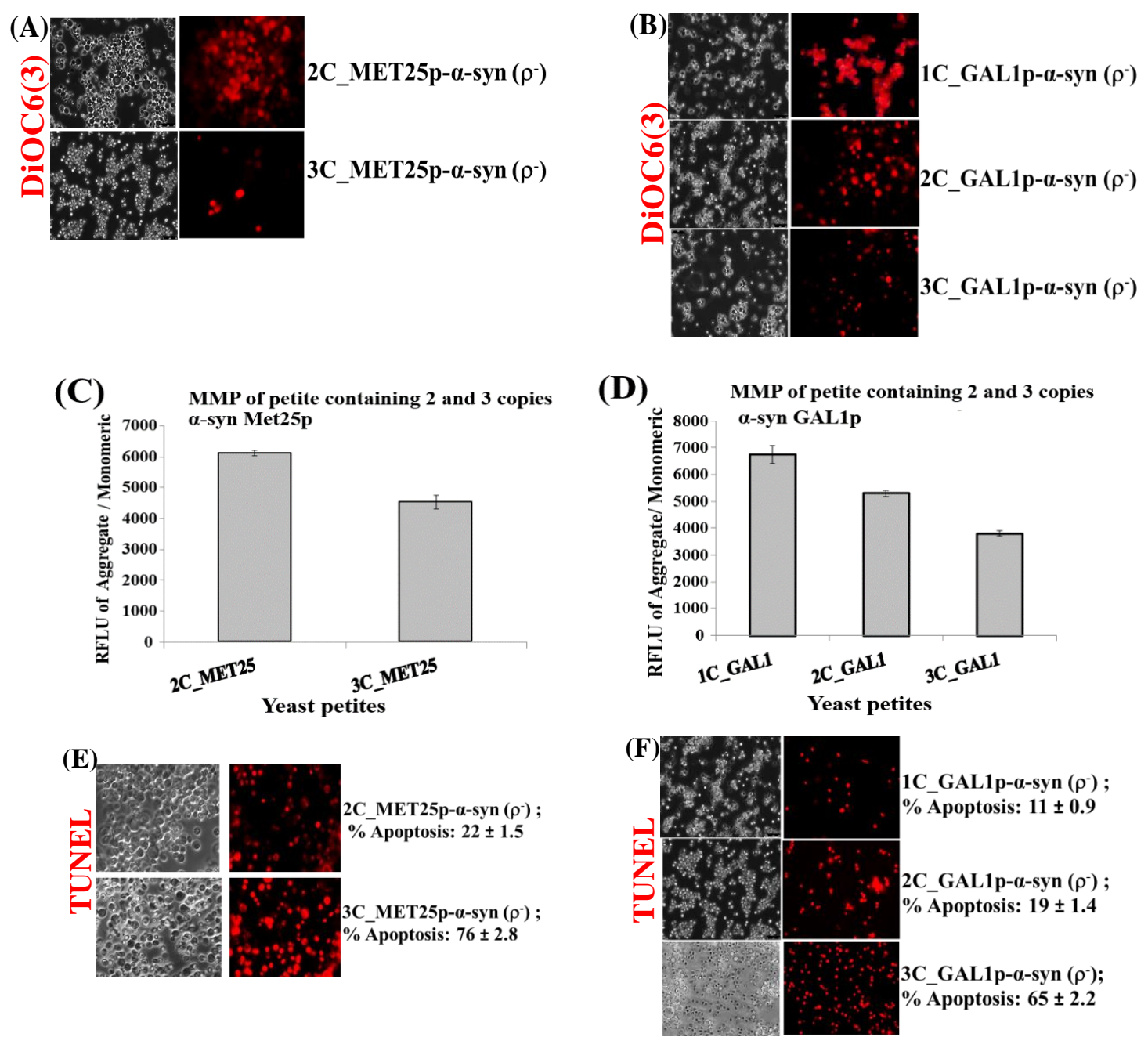

Figure 3. (A,B) Microscopic images $(\times 400)$ of staining of $\rho^{-}$petite transformants, that bear chromosomally integrated $\alpha$-syn-containing plasmids, with the dye DiOC6(3) that detects MMP in live cells. The images are representative images $(\times 400)$ of cells. $(C, D)$ Quantification of relative MMP of yeast cells expressing 2 and 3-copies of $\alpha$-syn from MET25p and 1-3-copies of $\alpha$-syn from GAL1p, using the JC-10 dye $(p<0.1)$. (E,F) Microscopic images $(\times 400)$ of nuclear DNA fragmentation, as observed using the TUNEL assay, in yeast cells expressing 2 and 3-copies of $\alpha$-syn from MET25p and 1-3-copies of $\alpha$-syn from GAL1p. The images are representative images of cells. The data in figures $(\mathbf{C}, \mathbf{D})$ represent mean \pm S.D. of three independent experiments $(p<0.1$; two-tailed $t$-test). The left-hand side pictures in $(\mathbf{A}, \mathbf{B}, \mathbf{E}, \mathbf{F})$ show phase-contrast microscopy pictures $(\times 400)$ of yeast cells. Post Hoc Newman-Keuls test, after a significant one-way ANOVA test, indicated a significant difference $p<0.001$ between strains expressing 2 and 3-copies of $\alpha$-syn from MET25p, and between 1 and 2-copies and 3-copies of $\alpha$-syn from GAL1p.

The results showed weaker staining of mitochondria in $\rho^{-}$petites that expressed 2 and 3 copies of $\alpha$-syn from GAL1p than cells expressing 1-copy of $\alpha$-syn from GAL1p. Similarly, mitochondria in cells 
expressing 2-copies of $\alpha$-syn from MET25p were more strongly stained than cells expressing 3-copies of $\alpha$-syn from MET25p. This would indicate that cells expressing lesser copies of $\alpha$-syn were more alive, with intact mitochondrial membranes, than cells that expressed more copies of $\alpha$-syn. This was corroborated by data obtained after quantification of mitochondrial membrane potential (MMP) [52], on a fluorescence plate reader, using the JC-10 MMP assay kit (Abcam; Figure 3C,D). It confirmed that $\rho^{-}$petites, formed upon minimal expression of $\alpha$-syn, when expressing 1 or 2 -copies of $\alpha$-syn have higher MMP compared to petites that expressed 2 or 3-copies of $\alpha$-syn. This reflected increased toxicity within cells as $\alpha$-syn copy number increased, and also indicated that the 3-copy $\alpha$-syn strain suffered the most mitochondrial dysfunction.

$\mathrm{P}^{-}$petite cells, which underwent loss of MMP with increasing $\alpha$-syn copy number, were then assessed via TUNEL assay to determine whether nuclear DNA fragmentation, a hallmark of apoptosis [53], occurred in these cells. The results clearly showed that $\rho^{-}$petites that suffered most apoptosis were the cells that expressed 3-copies of $\alpha$-syn from MET25p or GAL1p (Figure 3E,F). It was observed that one copy of $\alpha$-syn under the control of Met25 did not produce petite, and also from Figure 2A,B, $\alpha$-syn was seen to be more toxic under the control of GAL1p. This observation could be due to the promoter effect. The Peptone and yeast extract complex substrates (in YPD medium) contain amino acids to support growth; this includes Methionine, which represses Met25p. Although we saw cell death after Met25 induction, YPD contains low indefinite amounts of Methionine, and this could affect the strength of the Met25 promoter, and hence, $\alpha$-syn toxicity. The difference in $\alpha$-syn toxicity between the two promoters (GAL1p and Met25p) could be due to the above condition.

\subsection{Yeast Petite Cells Generated from $\rho^{+}$Basic Yeast Strain Do Not Contain mtDNA or Functional Mitochondrial Membranes}

$\rho^{-}$petites were spontaneously formed during minimal expression of $\alpha$-syn in $\rho^{+}$cells. We then decided to find out the consequence of expressing $\alpha$-syn in a chemically-induced respiration-deficient $\rho^{0}$ yeast strain. Hence, $\rho^{+}$BC300 grande cells were treated with ethidium bromide to create strains devoid of mtDNA [43]. The cells obtained after ethidium bromide treatment were at first clonally selected to identify cells that did not respire (i.e., cells that did not grow on Glycerol). The growth of eight such clones, on agar plates, is shown in Figure 4A.

The cells from one of these clonally-selected strains were then stained with SYTO18 and DiOC6(3), which showed complete absence of mtDNA and functional mitochondrial membranes, respectively (Figure $4 B, C$ ), suggesting that the strain was a $\rho^{0}$ derivative of BC 300 . The $\rho^{0}$ and $\rho^{+}$grande cells displayed no difference after staining with Phloxine $B$, indicating that, besides lacking mtDNA and functional mitochondrial membranes, the $\rho^{0}$ cells are as alive as the $\rho^{+}$cells (Figure 4D).

3.5. $\rho^{0}$ Yeast Petite Cells, that Bear MET25p- $\alpha$-Syn Integrative Plasmids, on Expression of $\alpha$-Syn Undergo Cell Death and Nuclear DNA Fragmentation (Apoptosis)

The $\rho^{0} \mathrm{BC} 300$ strain was then sequentially transformed with MET25p- $\alpha$-syn bearing integrative plasmids (Supplementary Materials, Part 1) to obtain strains that contained 1-3 copies of $\alpha$-syn. The MET25p-driven $\alpha$-syn integrative plasmids were chosen over the GAL1p-driven $\alpha$-syn integrative plasmids mainly because of the full expression of $\alpha$-syn from MET25p can occur in a glucose-containing medium. In contrast, expression from GAL1p requires medium containing galactose, which allows growth primarily under respiratory conditions [54]. Since $\rho^{0}$ cells completely lack respiratory capacity, we thought it would be inadvisable to use the GAL1p constructs.

The $\rho^{0}$ yeast strains containing MET25p-driven $\alpha$-syn expression cassettes in 1-3 copies were used to find out if they could undergo cell death, and more specifically, apoptosis when $\alpha$-syn was fully expressed from the MET25 promoter, namely, in complete YPD medium lacking methionine. At first, the $\rho^{0}$ transformants were grown on YPD agar plates for $96 \mathrm{~h}$ at $30{ }^{\circ} \mathrm{C}$ (Figure 5A). 


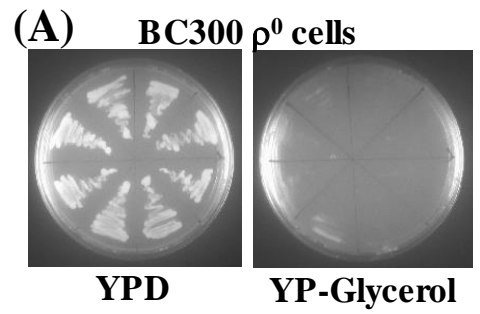

(C)

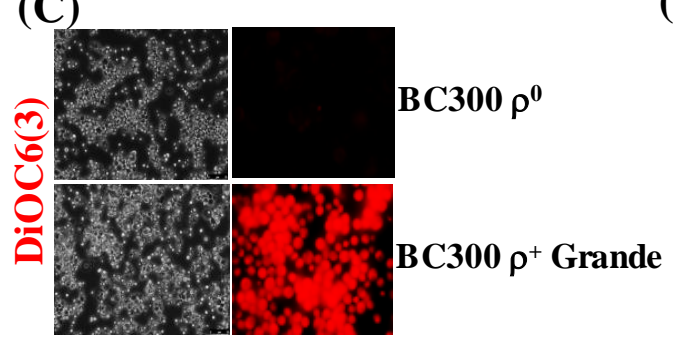

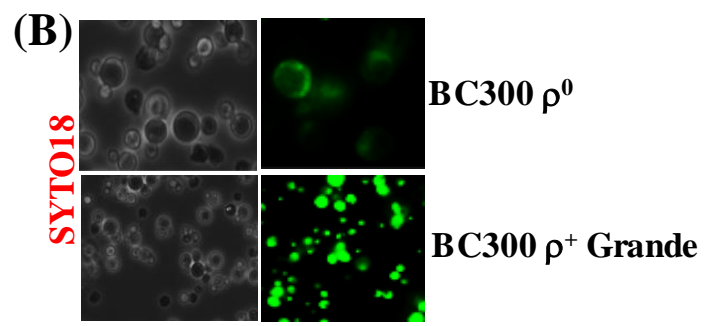

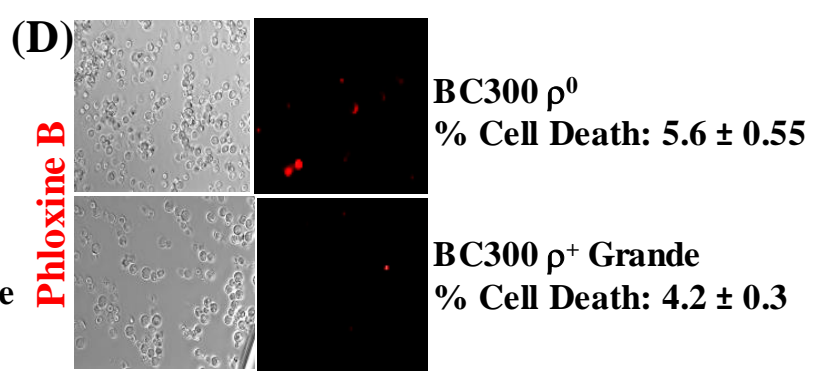

Figure 4. (A) Representative pictures of growth of $\rho^{0}$ BC300 yeast cells, formed after ethidium bromide treatment, on complete medium solid agar plates that contained either glucose (YPD) or Glycerol (YP-glycerol). (B) Microscopic images $(\times 600)$ of $\rho^{0}$ petite and $\rho^{+}$grande BC300 cells stained with the fluorescent dye SYTO18, which selectively stains yeast mtDNA. (C) Staining of $\rho^{0}$ petite and $\rho^{+}$BC300 cells with the dye DiR/DiOC6(3) that detects MMP in live cells $(\times 400)$. (D) Microscopic images $(\times 400)$ of $\rho^{0}$ petite and $\rho^{+}$BC300 cells stained with Phloxine B. Post Hoc Newman-Keuls test after a significant one-way ANOVA test, indicated a significant difference $p<0.001$ between $\rho^{0}$ petite and $\rho^{+}$BC300 strains in experiments $(\mathbf{B}, \mathbf{C})$, whereas, statistically, there was no difference between $\rho^{0}$ petite and $\rho^{+}$ cells in (D).

The $\rho^{0}$ cells containing 1-copy of $\alpha$-syn grew upon expression of the protein on a YPD plate. Cells containing 2 and 3 copies, however, did not grow, implying that comparatively lower levels of $\alpha$-syn produced from 1-copy gene expression cannot block cell growth on plates. The expression of $\alpha$-syn in the 1-3 copy $\alpha$-syn-containing $\rho^{0}$ cells was then assessed via Western blotting, after growing cells in YPD liquid medium for $50 \mathrm{~h}$ at $30^{\circ} \mathrm{C}$ (Figure 5B). Densitometric quantification showed that the 3-copy strain expressed the highest amount of $\alpha$-syn (see Supplementary Materials, Part 5). The same 1-3 copy $\alpha$-syn-containing $\rho^{0}$ cells, grown in YPD liquid medium, were then stained with Phloxine B to determine the percentage of cell death (Figure 5C). After that, the cells were tested for nuclear DNA fragmentation using the TUNEL assay (Figure 5D). There was a remarkable increase in cell death from 1-copy to 3-copy $\alpha$-syn expressing cells, as seen in both Phloxine B and TUNEL assays (Figure 5C,D). In parallel, the cells were stained with the blue fluorescent dye Hoechst 33,342 (Figure 5E), which stains the DNA and nuclei of live cells [55]. It was clearly seen that there were far more live cells in the 1 and 2 -copy $\alpha$-syn-containing $\rho^{0}$ cells than in cells expressing 3-copies of $\alpha$-syn.

3.6. Like $\rho^{+}$Cells, $\rho^{0}$ and $\rho^{-}$Cells Undergo Apoptosis When $\alpha$-Syn is Expressed from the MET25 Promoter in Complete YPD Medium

The TUNEL assay was used to compare nuclear DNA fragmentation (NDF), a hallmark of apoptosis, that was seen to occur in $\rho^{+}, \rho^{-}$and $\rho^{0}$ cells expressing $\alpha$-syn from MET25p. In all cells, plasmids bearing $\alpha$-syn expression cassettes had been integrated at different chromosomal loci (at HIS3 for 1-copy, HIS3, URA3 for 2-copies, and HIS3, URA3, TRP1 for 3-copies). All recombinant cells were grown in YPD (lacking methionine) for $20 \mathrm{~h}$ at $30^{\circ} \mathrm{C}$ for full induction of the MET25p. The comparative results are presented in Figure 6A and show that levels of NDF in $\rho^{+}, \rho^{-}$and $\rho^{0}$ cells expressing 3 -copies of $\alpha$-syn are similar. 


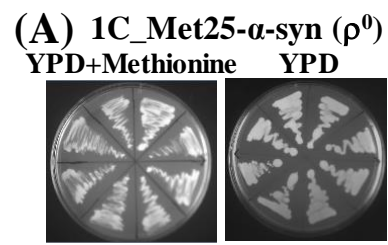

2C_Met25- $\alpha$-syn $\left(\rho^{0}\right)$
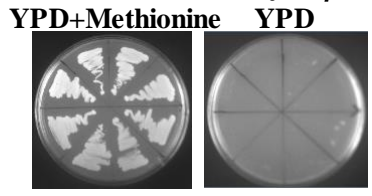

3C_Met25- $\alpha$-syn $\left(\rho^{0}\right)$ YPD+Methionine YPD

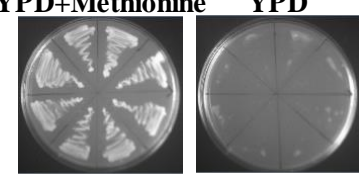

(B) $1 \quad 2 \quad 3$

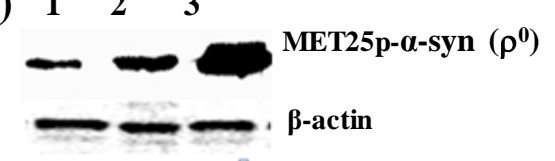

(C)

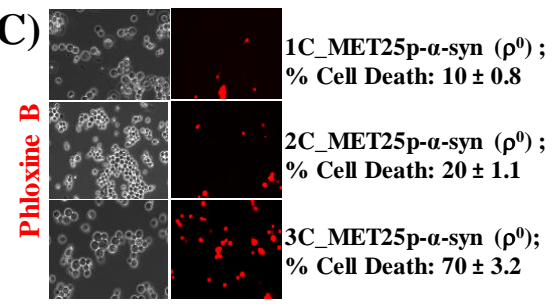

(D)

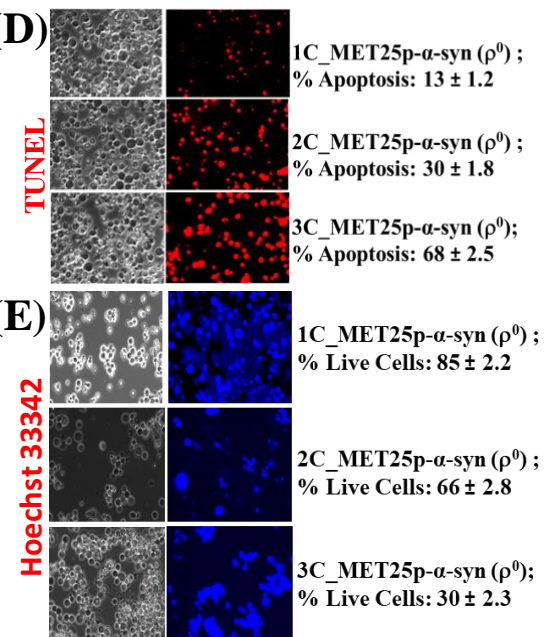

Figure 5. (A) Representative pictures of growth of $\rho^{0}$ yeast cells harboring 1-copy (1C), 2-copies (2C), and 3-copies (3C) of the human $\alpha$-syn gene, under the control of either MET25p, on complete YPD medium agar plates in the presence (YPD + Methionine) or absence (YPD) of methionine. (B) Western blot analyses of $\rho^{0}$ cells expressing 1-copy (lane 1), 2-copies (lane 2), and 3-copies (lane 3) of $\alpha$-syn protein. On lanes 1, 2, and 3 were loaded $7.5 \mu \mathrm{g}$ of total protein obtained after lysis of cells. The upper panel was probed with an antibody that recognizes the HA epitope (Proteintech, 51064-2-AP) and the lower panel with a $\beta$-actin antibody (Proteintech, 60008-1-Ig); levels of $\beta$-actin were used as loading controls, $\beta$-actin being a housekeeping gene. (C) Microscopic images $(\times 400)$ of $\rho^{0}$ cells, stained with Phloxine B, after the expression of 1-3 copies of $\alpha$-syn from the MET25p. (D) Microscopic images $(\times 400)$ of nuclear DNA fragmentation, as observed using the TUNEL assay, in $\rho^{0}$ yeast cells expressing 1-3-copies of $\alpha$-syn from MET25p. (E) $\rho^{0}$ cells, bearing 1-3 copies of MET25p-driven $\alpha$-syn expression cassettes, were stained with Hoechst 33,342 (a blue dye that labels DNA of live cells). Post Hoc Newman-Keuls test after a significant one-way ANOVA test, indicated a significant difference between petites expressing 1-3 copies of $\alpha$-syn.

Since the expression of human $\alpha$-syn in baker's yeast results in the accumulation of ROS, followed by the manifestation of apoptosis [56], ROS levels were measured (Figure 6B). Results showed that $\alpha$-syn generates ROS both in $\rho^{-}$and $\rho^{0}$ cells, as in $\rho^{+}$cells. MMP was also measured in all cell types (Figure 6C) because $\alpha$-syn aggregation has been reported to cause mitochondrial dysfunction, thereby affecting MMP [41]. The results with $\rho^{0}$ cells stood out; MMP levels were minuscule since $\rho^{0}$ cells do not contain any mitochondria (was shown not to stain with SYTO18 and DiOC6(3), as shown in Figure 4B,C). The JC-10 dye concentrates in the mitochondrial matrix-forming red fluorescent aggregates. In apoptotic cells, JC-10 diffuses out of mitochondria and changes to a monomeric form, which emits green fluorescence. However, cells that do not contain mitochondria (i.e., $\rho^{0}$ cells), JC-10 cannot concentrate on the mitochondria at all. The ratio of aggregated/monomeric JC-10 reflected that (Figure 6C). In hereditary genetics, inherited mitochondrial defects linked to mitochondrial dysfunction have been described in neurodegenerative disorders [57]. As of yet, the relationship between PD and mitochondrial dysfunction is unclear [21]. Polymorphisms related to mitochondrial genes are involved both in PD and also in Alzheimer's disease (AD). PD is explicitly associated with oxidative stress and mitochondrial dysfunction in neurons of the substantia nigra, which ultimately 
leads to neurodegeneration $[58,59]$. However, this report is inconsistent with experiments published elsewhere [60]. Partial mitochondrial dysfunction, as seen in rho- yeast petites is linked to the symptoms of Parkinson's disease (PD) [12,13]. Neuronal cell death in PD, as in $\alpha$-syn-induced yeast apoptosis, occurs from complete loss of mitochondrial function [14,15]. However, in human cells, the petite formation can occur spontaneously when mitochondrial function is partially disturbed by mtDNA mutations. This is the basis of most human neurological disorders [23]. Remarkably, artificially-created mtDNA-lacking human rho0 cells, although more resistant to apoptosis than rho+ cells, can still undergo cell death [25]. This is in contrast to the observation that cells with a deficiency in their respiratory chain may have increased apoptosis in vivo [26].

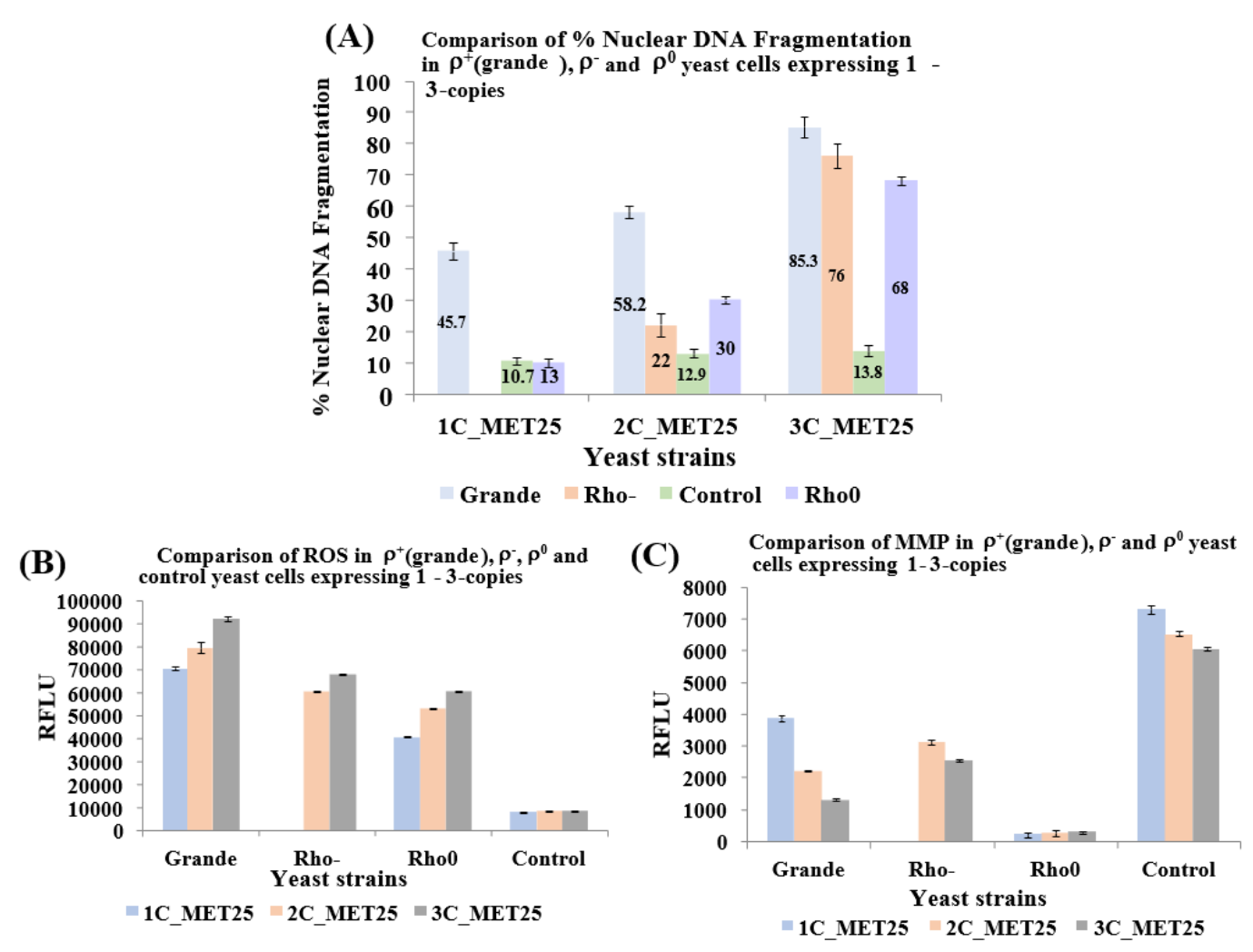

Figure 6. Analysis of nuclear DNA fragmentation (A), an increase of reactive oxygen species (ROS; B), and loss of mitochondrial membrane potential (MMP; C), in $\rho^{0}$ yeast cells that bear 1 to 3-copies of the human $\alpha$-syn, gene under the control of the MET25 promoter. (A) Levels of nuclear DNA fragmentation, a hallmark of apoptosis, in yeast cells that express 1 to 3-copies of $\alpha$-syn were assessed using the TUNEL assay. (B) Cells were stained with dihydroethidine to detect ROS. (C) Cells were stained with the JC-10 dye to quantify MMP loss. The data presented in $(\mathbf{A}, \mathbf{B}, \mathbf{C})$ represent mean \pm S.D. of three independent experiments $(p<0.05)$.

\section{Conclusions}

Here, we show that human $\alpha$-syn, when minimally expressed in yeast, has the unusual ability to form rho-petites. The results obtained after full expression of $\alpha$-syn in rho- and rho0 yeast cells showed some death in the petite cells; this indicates that mitochondrial function is not an absolute requirement for $\alpha$-syn-mediated apoptosis. The spontaneous formation of rho-petites by low-level expression of human $\alpha$-syn in yeast could help in understanding the pathogenesis of Parkinson's disease (PD) and its pathophysiology. Human cells usually cannot survive with a total loss of mitochondrial function, implying that impairment in mammalian cell mitochondrial, could result in apoptosis (cell death). Petite formation was not seen in mutant $\alpha$-syn (A53 and A30P) in yeast. One could imagine that neuronal cells in PD initially suffer from the petite formation, which later undergoes death 
(i.e., neurodegeneration), as seen in PD, during the progression of the disease. $\alpha$-syn-expressing yeast cells undergo a dose-dependent transit from mitochondrial loss to cell death. Therefore, high levels of alpha-syn are still able to induce cell death in cells that have previously lost mitochondrial respiratory function. Hence, functional mitochondria may be dispensable, but the loss of mitochondrial function may be essential for alpha-syn-induced cell death, as Partial mitochondrial dysfunction has been linked to the symptoms of Parkinson's disease (PD).

Supplementary Materials: The following are available online at http:/www.mdpi.com/2073-4409/9/10/2203/s1. Part 1: Construction of Yeast Strains that Contain 1-Copy, 2- And 3-Copies Of The Human $\alpha$-Syn Gene Driven by the MET25 Promoter (MET25P); Part 2: Construction of Yeast Strains that Contain 1-copy, 2- and 3-Copies of the Human $\alpha$-Syn Gene Driven by the GAL1 Promoter (GAL1p); Part 3: Densitometric Quantification of Western Blot Protein Bands after the expression of 2- and 3-Copies of $\alpha$-Syn Gene from MET25p, in $\rho^{-}$Petite Yeast Cells; Part 4: Densitometric Quantification of Western Blot Protein Bands after the expression of 2 and 3-Copies of $\alpha$-Syn Gene from GAL1p, in $\rho^{-}$Petite Yeast Cells; Part 5: Densitometric Quantification of Western Blot Protein Bands after the expression of 1, 2 and 3-Copies of $\alpha$-Syn Gene from MET25p, in $\rho^{0}$ Petite Yeast Cells; Part 6: Strain table.

Author Contributions: D.D.A. performed all the experiments. B.C. coordinated the study. B.C. and D.D.A. wrote the manuscript. All authors have read and agreed to the published version of the manuscript.

Funding: Funds from De Montfort University supported this work.

Acknowledgments: D.D.A. acknowledges De Montfort University for support.

Conflicts of Interest: The authors declare no conflict of interest.

\section{References}

1. Eid, R.; Zhou, D.R.; Arab, N.T.T.; Boucher, E.; Young, P.G.; Mandato, C.A.; Greenwood, M.T. Heterologous expression of anti-apoptotic human 14-3-3 $\beta / \alpha$ enhances iron-mediated programmed cell death in yeast. PLoS ONE 2017, 12, e0184151. [CrossRef] [PubMed]

2. Hou, J.; Acharya, L.; Zhu, N.; Cheng, J. An overview of bioinformatics methods for modeling biological pathways in yeast. Brief. Funct. Genom. 2015, 15, 95-108. [CrossRef] [PubMed]

3. Mohammadi, S.; Saberidokht, B.; Subramaniam, S.; Grama, A. Scope and limitations of yeast as a model organism for studying human tissue-specific pathways. BMC Syst. Boil. 2015, 9, 1-22. [CrossRef]

4. Zhang, G.; Xia, Y.; Wan, F.; Ma, K.; Guo, X.; Kou, L.; Yin, S.; Han, C.; Liu, L.; Huang, J.; et al. New Perspectives on Roles of Alpha-Synuclein in Parkinson's Disease. Front. Aging Neurosci. 2018, 10. [CrossRef] [PubMed]

5. Miyakawa, I.; Nakahara, A.; Ito, K. Morphology of mitochondrial nucleoids, mitochondria, and nuclei during meiosis and sporulation of the yeast Saccharomycodes ludwigii. J. Gen. Appl. Microbiol. 2012, 58, 43-51. [CrossRef]

6. Rostovtseva, T.K.; Gurnev, P.A.; Protchenko, O.; Hoogerheide, D.P.; Yap, T.L.; Philpott, C.C.; Lee, J.C.; Bezrukov, S.M. $\alpha$-Synuclein Shows High Affinity Interaction with Voltage-dependent Anion Channel, Suggesting Mechanisms of Mitochondrial Regulation and Toxicity in Parkinson Disease. J. Boil. Chem. 2015, 290, 18467-18477. [CrossRef]

7. Akintade, D.D.; Chaudhuri, B. Sensing the Generation of Intracellular Free Electrons Using the Inactive Catalytic Subunit of Cytochrome P450s as a Sink. Sensors 2020, 20, 4050. [CrossRef]

8. Federico, A.; Cardaioli, E.; Da Pozzo, P.; Formichi, P.; Gallus, G.N.; Radi, E. Mitochondria, oxidative stress and neurodegeneration. J. Neurol. Sci. 2012, 322, 254-262. [CrossRef]

9. Cheng, W.-C.; Teng, X.; Park, H.K.; Tucker, C.M.; Dunham, M.J.; Hardwick, J.M. Fis1 deficiency selects for compensatory mutations responsible for cell death and growth control defects. Cell Death Differ. 2008, 15, 1838-1846. [CrossRef]

10. Roberts, G.G.; Hudson, A.P. Transcriptome profiling of Saccharomyces cerevisiae during a transition from fermentative to glycerol-based respiratory growth reveals extensive metabolic and structural remodeling. Mol. Genet. Genom. 2006, 276, 170-186. [CrossRef]

11. Ernst, D.C.; Downs, D.M. Mmf1p Couples Amino Acid Metabolism to Mitochondrial DNA Maintenance in Saccharomyces cerevisiae. Mbio 2018, 9. [CrossRef] [PubMed]

12. Weng, M.; Xie, X.; Liu, C.; Lim, K.-L.; Zhang, C.; Bai, L. The Sources of Reactive Oxygen Species and Its Possible Role in the Pathogenesis of Parkinson's Disease. Park. Dis. 2018, 2018, 1-9. [CrossRef] [PubMed] 
13. Schapira, A.H.V. Mitochondria in the aetiology and pathogenesis of Parkinson's disease. Lancet Neurol. 2008, 7, 97-109. [CrossRef]

14. Bose, A.; Beal, M.F. Mitochondrial dysfunction in Parkinson's disease. J. Neurochem. 2016, 139, $216-231$. [CrossRef]

15. Luo, Y.; Hoffer, A.; Hoffer, B.; Qi, X. Mitochondria: A Therapeutic Target for Parkinson's Disease? Int. J. Mol. Sci. 2015, 16, 20704-20730. [CrossRef] [PubMed]

16. Benskey, M.J.; Perez, R.G.; Manfredsson, F.P. The contribution of alpha synuclein to neuronal survival and function-Implications for Parkinson's disease. J. Neurochem. 2016, 137, 331-359. [CrossRef]

17. Burré, J.; Sharma, M.; Südhof, T.C. Definition of a molecular pathway mediating $\alpha$-synuclein neurotoxicity. J. Neurosci. 2015, 35, 5221-5232. [CrossRef]

18. Games, D.; Valera, E.; Spencer, B.; Rockenstein, E.; Mante, M.; Adame, A.; Patrick, C.; Ubhi, K.; Nuber, S.; Sacayon, P.; et al. Reducing C-Terminal-Truncated Alpha-Synuclein by Immunotherapy Attenuates Neurodegeneration and Propagation in Parkinson's Disease-Like Models. J. Neurosci. 2014, 34, 9441-9454. [CrossRef]

19. Chinta, S.J.; Mallajosyula, J.K.; Rane, A.; Andersen, J.K. Mitochondrial alpha-synuclein accumulation impairs complex I function in dopaminergic neurons and results in increased mitophagy in vivo. Neurosci. Lett. 2010, 486, 235-239. [CrossRef]

20. Ghiglieri, V.; Calabrese, V.; Calabresi, P. Alpha-Synuclein: From Early Synaptic Dysfunction to Neurodegeneration. Front. Neurol. 2018, 9. [CrossRef]

21. Flagmeier, P.; Meisl, G.; Vendruscolo, M.; Knowles, T.P.J.; Dobson, C.M.; Buell, A.K.; Galvagnion, C. Mutations associated with familial Parkinson's disease alter the initiation and amplification steps of $\alpha$-synuclein aggregation. Proc. Natl. Acad. Sci. USA 2016, 113, 10328-10333. [CrossRef] [PubMed]

22. Heude, M.; Fukuhara, H.; Moustacchi, E. Spontaneous and induced rho mutants of Saccharomyces cerevisiae: Patterns of loss of mitochondrial genetic markers. J. Bacteriol. 1979, 139, 460-467. [CrossRef] [PubMed]

23. Wilkins, H.M.; Carl, S.M.; Swerdlow, R.H. Cytoplasmic hybrid (cybrid) cell lines as a practical model for mitochondriopathies. Redox Boil. 2014, 2, 619-631. [CrossRef]

24. Kukat, A.; Kukat, C.; Brocher, J.; Schäfer, I.; Krohne, G.; Trounce, I.A.; Villani, G.; Seibel, P. Generation of $\rho 0$ cells utilizing a mitochondrially targeted restriction endonuclease and comparative analyses. Nucleic Acids Res. 2008, 36, e44. [CrossRef] [PubMed]

25. Fernandez-Moreno, M.; Hermida-Gómez, T.; Gallardo, M.E.; Dalmao-Fernández, A.; Rego-Perez, I.; Garesse, R.; Blanco, F.J. Generating Rho-0 Cells Using Mesenchymal Stem Cell Lines. PLoS ONE 2016, 11, e0164199. [CrossRef] [PubMed]

26. Wang, J.; Silva, J.P.; Gustafsson, C.M.; Rustin, P.; Larsson, N.-G. Increased in vivo apoptosis in cells lacking mitochondrial DNA gene expression. Proc. Natl. Acad. Sci. USA 2001, 98, 4038-4043. [CrossRef]

27. Marchetti, P.A.; Susin, S.; Decaudin, D.; Gamen, S.; Castedo, M.; Hirsch, T.; Zamzami, N.; Naval, J.; Senik, A.; Kroemer, G. Apoptosis-associated derangement of mitochondrial function in cells lacking mitochondrial DNA. Cancer Res. 1996, 56, 2033-2038.

28. Aouida, M.; Mekid, H.; Belhadj, O.; Mir, L.M.; Tounekti, O. Mitochondria-independent morphological and biochemical apoptotic alterations promoted by the anti-tumor agent bleomycin in Saccharomyces cerevisiae. Biochem. Cell Boil. 2007, 85, 49-55. [CrossRef]

29. Franssens, V.; Boelen, E.; Anandhakumar, J.; Vanhelmont, T.; Büttner, S.; Winderickx, J. Yeast unfolds the road map toward $\alpha$-synuclein-induced cell death. Cell Death Differ. 2009, 17, 746-753. [CrossRef]

30. Greenhalf, W.; Stephan, C.; Chaudhuri, B. Role of mitochondria and C-terminal membrane anchor of Bcl-2 in Bax induced growth arrest and mortality in Saccharomyces cerevisiae. FEBS Lett. 1996, 380, 169-175. [CrossRef]

31. Côrte-Real, M.; Madeo, F. Yeast Programed Cell Death and Aging. Front. Oncol. 2013, 3. [CrossRef] [PubMed]

32. Gourlay, C.W.; Ayscough, K.R. Actin-Induced Hyperactivation of the Ras Signaling Pathway Leads to Apoptosis in Saccharomyces cerevisiae. Mol. Cell. Boil. 2006, 26, 6487-6501. [CrossRef] [PubMed]

33. Ludovico, P.; Sousa, M.J.; Silva, M.T.; Leäo, C.; Côrte-Real, M. Saccharomyces cerevisiae commits to a programmed cell death process in response to acetic acid. Microbiology 2001, 147, 2409-2415. [CrossRef] [PubMed]

34. Severin, F.; Hyman, A.A. Pheromone Induces Programmed Cell Death in S. cerevisiae. Curr. Boil. 2002, 12, R233-R235. [CrossRef] 
35. Narasimhan, M.L.; Damsz, B.; Coca, M.A.; Ibeas, J.I.; Yun, D.-J.; Pardo, J.M.; Hasegawa, P.M.; Bressan, R.A. A Plant Defense Response Effector Induces Microbial Apoptosis. Mol. Cell. 2001, 8, 921-930. [CrossRef]

36. Silva, R.D.; Sotoca, R.; Johansson, B.; Ludovico, P.; Sansonetty, F.; Silva, M.T.; Peinado, J.M.; Côrte-Real, M. Hyperosmotic stress induces metacaspase- and mitochondria-dependent apoptosis in Saccharomyces cerevisiae. Mol. Microbiol. 2005, 58, 824-834. [CrossRef]

37. Pereira, C.; Chaves, S.R.; Alves, S.; Salin, B.; Camougrand, N.; Manon, S.; Sousa, M.J.; Côrte-Real, M. Mitochondrial degradation in acetic acid-induced yeast apoptosis: The role of Pep4 and the ADP/ATP carrier. Mol. Microbiol. 2010, 76, 1398-1410. [CrossRef]

38. Alic, N.; Higgins, V.J.; Pichova, A.; Breitenbach, M.; Dawes, I.W.; Yao, Y.-L.; Yang, W.-M. Lipid Hydroperoxides Activate the Mitogen-activated Protein Kinase Mpk1p in Saccharomyces cerevisiae. J. Boil. Chem. 2003, 278, 41849-41855. [CrossRef]

39. Elfawy, H.A.; Das, B. Crosstalk between mitochondrial dysfunction, oxidative stress, and age related neurodegenerative disease: Etiologies and therapeutic strategies. Life Sci. 2019, 218, 165-184. [CrossRef]

40. Panchal, K.; Tiwari, A.K. Mitochondrial dynamics, a key executioner in neurodegenerative diseases. Mitochondrion 2019, 47, 151-173. [CrossRef]

41. Akintade, D.D.; Chaudhuri, B. The effect of copy number on $\alpha$-synuclein's toxicity and its protective role in Bax-induced apoptosis, in yeast. Biosci. Rep. 2020, 40. [CrossRef]

42. Büttner, S.; Faes, L.; Reichelt, W.; Broeskamp, F.; Habernig, L.; Benke, S.; Kourtis, N.; Ruli, D.; Carmona-Gutierrez, D.; Eisenberg, T.; et al. The $\mathrm{Ca}^{2+} / \mathrm{Mn}^{2+}$ ion-pump PMR1 links elevation of cytosolic $\mathrm{Ca}^{2+}$ levels to $\alpha$-synuclein toxicity in Parkinson's disease models. Cell Death Differ. 2013, 20, 465-477. [CrossRef] [PubMed]

43. Goldring, E.S.I.; Grossman, L.; Krupnick, D.; Cryer, D.R.; Marmur, J. The petite mutation in yeast. Loss of mitochondrial deoxyribonucleic acid during induction of petites with ethidium bromide. J. Mol. Boil. 1970, 52, 323-335. [CrossRef]

44. Kawai, S.; Hashimoto, W.; Murata, K. Transformation of Saccharomyces cerevisiae and other fungi: Methods and possible underlying mechanism. Bioeng. Bugs. 2010, 1, 395-403. [CrossRef] [PubMed]

45. Cottet-Rousselle, C.; Ronot, X.; Leverve, X.; Mayol, J.-F. Cytometric assessment of mitochondria using fluorescent probes. Cytom. Part A 2011, 79, 405-425. [CrossRef]

46. Swayne, T.C.; Lipkin, T.G.; Pon, L.A. Live-Cell Imaging of the Cytoskeleton and Mitochondrial-Cytoskeletal Interactions in Budding Yeast. Adv. Struct. Saf. Stud. 2009, 586, 41-68. [CrossRef]

47. Kwolek-Mirek, M.; Zadrag-Tecza, R. Comparison of methods used for assessing the viability and vitality of yeast cells. FEMS Yeast Res. 2014, 14, 1068-1079. [CrossRef]

48. Derf, A.; Mudududdla, R.; Akintade, D.; Williams, I.S.; Abdullaha, M.; Chaudhuri, B.; Bharate, S.B. Nonantioxidant Tetramethoxystilbene Abrogates $\alpha$-Synuclein-Induced Yeast Cell Death but Not That Triggered by the Bax or $\beta$ A4 Peptide. ACS Omega. 2018, 3, 9513-9532. [CrossRef]

49. Von Der Haar, T. Optimized Protein Extraction for Quantitative Proteomics of Yeasts. PLoS ONE 2007, 2, e1078. [CrossRef]

50. Maya, D.; Quintero, M.J.; Muñoz-Centeno, M.D.L.C.; Chàvez, S.; Muñoz-Centeno, M.C. Systems for applied gene control in Saccharomyces cerevisiae. Biotechnol. Lett. 2008, 30, 979-987. [CrossRef]

51. Peng, B.; Williams, T.; Henry, M.; Nielsen, L.K.; Vickers, C.E. Controlling heterologous gene expression in yeast cell factories on different carbon substrates and across the diauxic shift: A comparison of yeast promoter activities. Microb. Cell Factories 2015, 14, 91. [CrossRef] [PubMed]

52. Farrelly, E.; Amaral, M.; Marshall, L.; Huang, S.-G. A High-Throughput Assay for Mitochondrial Membrane Potential in Permeabilized Yeast Cells. Anal. Biochem. 2001, 293, 269-276. [CrossRef] [PubMed]

53. Falcone, C.; Mazzoni, C. External and internal triggers of cell death in yeast. Cell. Mol. Life Sci. 2016, 73, 2237-2250. [CrossRef] [PubMed]

54. Renvoisé, M.; Bonhomme, L.; Davanture, M.; Valot, B.; Zivy, M.; Lemaire, C. Quantitative variations of the mitochondrial proteome and phosphoproteome during fermentative and respiratory growth in Saccharomyces cerevisiae. J. Proteom. 2014, 106, 140-150. [CrossRef] [PubMed]

55. Lin, K.K.; Goodell, M.A. Detection of Hematopoietic Stem Cells by Flow Cytometry. Elsevier BV 2011, 103, 21-30.

56. Akintade, D.D.; Chaudhuri, B. Identification of proteins involved in transcription/translation (eEF 1A1) as an inhibitor of Bax induced apoptosis. Mol. Boil. Rep. 2020, 2020, 1-8. [CrossRef] 
57. Morais, V.A.; De Strooper, B. Mitochondria Dysfunction and Neurodegenerative Disorders: Cause or Consequence. J. Alzheimer's Dis. 2010, 20, S255-S263. [CrossRef]

58. Ganguly, G.; Chakrabarti, S.; Chatterjee, U.; Saso, L. Proteinopathy, oxidative stress and mitochondrial dysfunction: Cross talk in Alzheimer's disease and Parkinson's disease. Drug Des. Dev. Ther. 2017, 11, 797-810. [CrossRef]

59. Puspita, L.; Chung, S.Y.; Shim, J.-W. Oxidative stress and cellular pathologies in Parkinson's disease. Mol. Brain. 2017, 10, 53. [CrossRef]

60. Szklarz, L.K.S.; Kozjak-Pavlovic, V.; Vögtle, F.-N.; Chacinska, A.; Milenkovic, D.; Vogel, S.; Dürr, M.; Westermann, B.; Guiard, B.; Martinou, J.-C.; et al. Preprotein Transport Machineries of Yeast Mitochondrial Outer Membrane Are not Required for Bax-induced Release of Intermembrane Space Proteins. J. Mol. Boil. 2007, 368, 44-54. [CrossRef]

(C) 2020 by the authors. Licensee MDPI, Basel, Switzerland. This article is an open access article distributed under the terms and conditions of the Creative Commons Attribution (CC BY) license (http://creativecommons.org/licenses/by/4.0/). 